\title{
Keeping it Clean: Tips on Cleaning Floors ${ }^{1}$
}

Mary N. Harrison ${ }^{2}$

It's important to keep floors clean. Dirty floors are unhealthy, especially for children who are on the floor more often.

You Need:

- Broom

- Mop

- Water

- Detergent

-(Optional) wax for specific types of floors

-(Optional) electric broom or vacuum cleaner

\section{Daily Floor Care}

- Use mats inside and outside the entrance to catch tracked-in dirt and protect the floor finish. Mats can be cleaned easily. Use non-skid mats.

- Sweep hard surface floors and especially those in the kitchen and dining area or use an electric broom.
- Wipe up spills and sticky spots immediately.

- Vacuum carpeted areas where there are children or pets.

- Protect the floor when moving heavy furniture.

\section{Weekly}

- Mop bathroom and kitchen floors.

- Vacuum carpeted floors at least once a week to remove dirt. Clean in the corners carefully.

- Wash mats and small rugs.

- Use an electric broom to clean hard surface floors and vacuum carpets.

\section{Monthly or More Often}

- Apply floor finish or "wax" floors.

1. This document is FCS5232-10, one of a series of the Family Youth and Community Sciences Department, Florida Cooperative Extension Service, Institute of Food and Agricultural Sciences, University of Florida. Original publication date June 2002. Revised November 2005. Visit the EDIS Web Site at http://edis.ifas.ufl.edu.

2. Mary N. Harrison, professor, Department of Family, Youth and Community Sciences, Cooperative Extension Service, Institute of Food and Agricultural Sciences, University of Florida, Gainesville, 32611.

The Institute of Food and Agricultural Sciences (IFAS) is an Equal Opportunity Institution authorized to provide research, educational information and other services only to individuals and institutions that function with non-discrimination with respect to race, creed, color, religion, age, disability, sex, sexual orientation, marital status, national origin, political opinions or affiliations. U.S. Department of Agriculture, Cooperative Extension Service, University of Florida, IFAS, Florida A. \& M. University Cooperative Extension Program, and Boards of County Commissioners Cooperating. Larry Arrington, Dean 


\section{Care Tips}

\section{Vinyl flooring}

- Use an all-purpose cleaner solution or water-based cleaner and polish for routine care.

- DO NOT use solvent-based cleaning products or waxes. It damages the vinyl.

- Do not allow greases or oil to get on the floor and do not use oiled mops or dust cloths.

- If a vinyl-backed floor mat with a colored lining or a throw rug is used on vinyl floor covering, the vinyl floor covering will become permanently stained.

\section{Carpet}

- Vacuum weekly. Areas where children and pets play should be cleaned daily. Dirty carpets can cause children with respiratory problems to get sick.

- Clean wall-to-wall carpet with an upright vacuum cleaner or a canister cleaner with a carpet beater.

- To remove stains, blot the spill carefully. DO NOT rub. Work from the outer edge toward the center. You may need to use a carpet stain remover.

- To remove odor sprinkle with baking soda. Let stand about 20 minutes, then vacuum.

\section{Resilient floor}

- Sweep or dust mop daily.

- Damp mop with mild detergent, then rinse with clean water to remove normal household dust. Wax occasionally.

-Wipe up spills immediately. Some household substances and food permanently stain resilient floor covering.

\section{Asphalt or rubber}

- Use mild detergent to mop. Rinse with clean water.

- Use water-based wax or polish regularly.

\section{Wood}

- Do not use water on natural finished wood.

- Wipe up spills immediately with a soft cloth.

- To clean, use a liquid wax for wood floors or a solvent cleaner. Use wax or a polish specifically formulated for wood.

\section{Compressed wood laminated flooring (ex, Pergo®)}

- Damp mop, but do not let it get water soaked.

- Do not wax. 